DOI:10.22337/2587-9618-2020-16-4-29-37

\title{
SIMULATION OF A MULTI-FREQUENCY STOCKBRIDGE VIBRATION DAMPER OSCILATIONS WITH ENERGY SCATTERING HYSTERESIS
}

\author{
Alexander N. Danilin, Alexey S. Kurbatov, Sergey I. Zhavoronok \\ Institute of Applied Mechanics of Russian Academy of Sciences, Moscow, RUSSIA \\ Moscow Aviation Institute (National Research University) - MAI, Moscow, RUSSIA
}

\begin{abstract}
Spatial vibrations of a system containing a cable and a mass (solid body of arbitrary spatial configuration) are modeled. The problem is solved in a geometrically linear formulation, taking into account the hysteresis of energy scattering that is based on the kinematic equation. Identification of its parameters is carried out on the basis of experimental data on hysteresis loops of the limit cycle.
\end{abstract}

Keywords: vibration damper, frequencies, waveforms, non-stationary oscillations, hysteresis, kinematic approach

\section{О МОДЕЛИРОВАНИИ КОЛЕБАНИЙ МНОГОЧАСТОТНОГО ГАСИТЕЛЯ ВИБРАЦИИ СТОКБРИДЖА С УЧЁТОМ ГИСТЕРЕЗИСА ЭНЕРГОРАССЕЯНИЯ}

\author{
А.Н. Данилин, А.С. Курбатов, С.И. Жаворонок \\ Институт прикладной механики Российской Академии наук, г. Москва, РОССИЯ \\ Московский авиационный институт (национальный исследовательский университет), г. Москва, РОССИЯ

\begin{abstract}
Аннотация: Моделируются пространственные колебания системы, состоящей из тросика и груза - твёрдого тела произвольной пространственной конфигурации. Задача решается в геометрически линейной постановке с учётом гистерезиса энергорассеяния на основе кинематического уравнения, идентификация параметров которого осуществляется по экспериментальных данных о гистерезисных петлях предельного цикла.
\end{abstract}

Ключевые слова: гаситель вибрации, частоты и формы колебаний, нестационарные колебания, гистерезис, кинематический подход

\section{INTRODUCTION}

Vibration protection of wires, lightning cables, fiber-optic communication cables in systems of overhead power lines (OL) is carried out by various methods. The main of them is protection with the help of multi-frequency vibration dampers, which are structurally similar to the Stockbridge ones [1$3]$. The typical design of such a damper consists of two mass connected by cables (flexible elements) with a clip that is rigidly fastened to the OL wire using a plate (Figure 1). The masses are located on different sides relative to the vertical axis of the clamp, in general, at different distances. The energy dissipation of vibrations occurs as a result of the mutual friction of the wire spirals from which the cable is made.

Experimental studies of the energy scattering of OL wires vibration dampers currently play a key role in the analysis of their effectiveness. However, it is important to create mathematical models of vibrations that allow not only to 
calculate the dynamic properties of dampers, but also to optimize their design parameters in order to increase the dissipation of vibration energy in the widest frequency range.

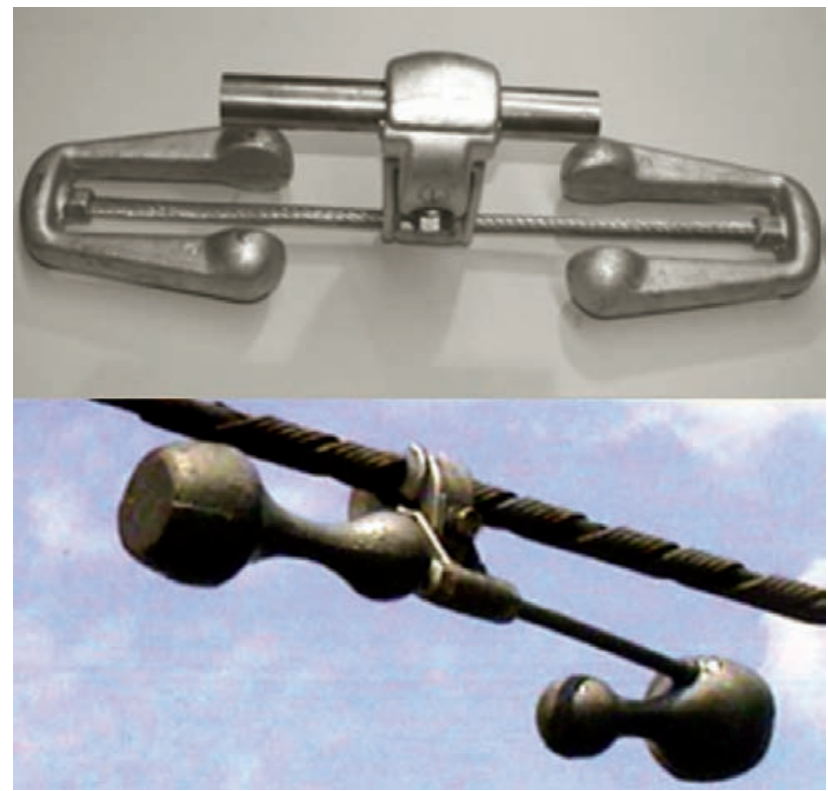

Figure 1. Vibration dampers conductors of $O L$

Energy dissipation occurs in the cable of the damper due to the elastic-plastic interaction of the wire spirals during their mutual friction. At the same time, as experiments show, the dependences of force factors on the corresponding kinematic parameters have a pronounced hysteresis character.

In this paper, we propose a kinematic model for describing hysteresis [4-6], according to which the bending and torsional momenta and their corresponding curvatures are connected by a special first-order differential equation, the coefficients of which are determined from experimental values for the limit cycle loop. In this case, one equation can describe an infinite set of similar trajectories, each of which is uniquely determined by the position of the initial point in the deformation diagram inside the limit cycle. The similarity of these curves is determined by their asymptotic approximation to the limit cycle curve. This model leads to a natural definition of the hysteresis cycle "orbital" under external non-stationary action on the damper.

\section{BASIC KINEMATIC RELATIONS}

Spatial vibrations of a system containing a cable and a mass (solid body of arbitrary spatial configuration) are considered. It is considered that one end of the cable is cantilevered, and the other is rigidly tethered to the mass. The gravitational load on the system is not taken into account. The cable axis is considered straight in the initial state.

A local trihedron of axes $O^{\prime} x^{\prime} y^{\prime} z^{\prime}$ is associated with the mass, which oscillates with the mass relative to a fixed coordinate system $O x y z$. The pole $O^{\prime}$ is aligned with intersection of the cable axis and the surface of the mass in the place of their rigid fastening.

A rod model is taken for a cable, assuming that its cross-sections are displaced in space as rigid non-deformable disks.

The oscillations are considered small, allowing one to represent the movements of the crosssection points of the cable with the coordinate in the form

$$
\begin{aligned}
& u(x, y, z)=u_{0}(x)+\theta_{2}(x) z-\theta_{3}(x) y, \\
& v(x, y, z)=v_{0}(x)-\theta_{1}(x) z, \\
& w(x, y, z)=w_{0}(x)+\theta_{1}(x) y
\end{aligned}
$$

Here $u_{0}, v_{0}, w_{0}$ are displacements of the crosssection pole; $\theta_{1}, \theta_{2}, \theta_{3}$ are rotation angles of the cross-section relative to the axes $x, y, z$, respectively.

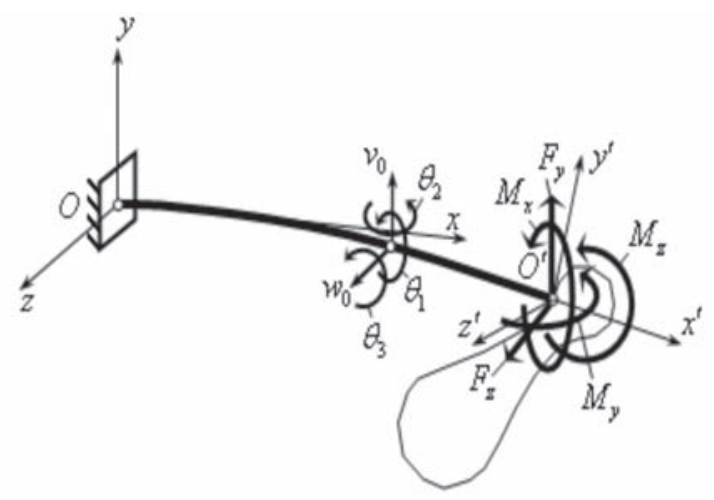

Figure 2. Coordinate axes, kinematic and power parameters of the "cable-weight" system 
System "cable-weight" and the related coordinate frame are shown in Figure 2. Here the positive directions of the displacements and rotation angles of an arbitrary section of the cable are also shown, as well as forces and moments acting on the cable and mass at the point of their contact.

\section{ELASTIC DEFORMATION RELATIONS}

Formulae (1) allow us to obtain the following expressions for strains:

$$
\begin{aligned}
& \varepsilon_{x}=\frac{\partial u}{\partial x}=u_{0}^{\prime}+\theta_{2}^{\prime}(x) z-\theta_{3}^{\prime}(x) y, \\
& \varepsilon_{y}=\frac{\partial v}{\partial y=0}, \varepsilon_{z}=\frac{\partial w}{\partial z}=0, \\
& \gamma_{x y}=\frac{\partial u}{\partial y}+\frac{\partial v}{\partial x}=-\theta_{3}+v_{0}^{\prime}-\theta_{1}^{\prime} z, \\
& \gamma_{x z}=\frac{\partial u}{\partial z}+\frac{\partial w}{\partial x}=\theta_{2}+w_{0}^{\prime}+\theta_{1}^{\prime} y .
\end{aligned}
$$

Here and further, the strokes denote the derivatives of the values in the direction of $x$, except for the notation for the moving coordinate system $O^{\prime} x^{\prime} y^{\prime} z^{\prime}$. The relationship between stresses and strains is assumed in the form of Hooke's law using some reduced elastic $E$ and shear modulus $G$. Then the axial stress $\sigma_{x}=E \varepsilon_{x}$, determines the axial force

$$
N=\int_{F} \sigma_{x} d F=E F\left(u_{0}-y_{C} \theta_{3}+z_{C} \theta_{2}\right)^{\prime}
$$

and bending moments

$$
\begin{aligned}
& M_{z}=-\int_{F} y \sigma_{x} d F=E\left(-y_{C} F u_{0}+\right. \\
& \left.+J_{z} \theta_{3}-J_{y z} \theta_{2}\right)^{\prime}, \\
& M_{y}=\int_{F} z \sigma_{x} d F=E\left(z_{C} F u_{0}-J_{y z} \theta_{3}+\right. \\
& \left.J_{y} \theta_{2}\right)^{\prime}
\end{aligned}
$$

where $y_{C}, z_{C}$ are the coordinates of the center of mass of the section relative to its pole.

Tangential stresses

$$
\tau_{x y}=G \gamma_{x y}, \tau_{x z}=G \gamma_{x z}
$$

determine the transverse forces

$$
\begin{aligned}
& Q_{y}=\int_{F c y} \tau_{x y} d F= \\
& =G F_{c y}\left[-\theta_{3}+\left(v_{0}-z_{g} \theta_{1}\right)^{\prime}\right], \\
& Q_{z}=\int_{F c z} \tau_{x z} d F=G F_{c z}\left[\theta_{2}+\left(w_{0}+y_{g} \theta_{1}\right)^{\prime}\right],
\end{aligned}
$$

as well as the torque

$$
\begin{aligned}
& M_{k}=\int_{F c y} \tau_{x y} y d F-\int_{F c z} \tau_{x z} z d F= \\
& =G J_{k} \theta_{1}^{\prime}+G F_{c z} y_{g}\left(\theta_{2}+w_{0}^{\prime}\right)+ \\
& +G F_{c y} z_{g}\left(\theta_{3}-v_{0}^{\prime}\right),
\end{aligned}
$$

where $y_{g}, z_{g}$ are the coordinates of the section stiffness center relative to its pole; $F_{c y}, F_{c z}$ are equivalent cross-sectional areas working for a shift in the direction of transverse forces $Q_{y}$ and $Q_{z}$;

$$
J_{k}=\int_{F c z} y^{2} d F+\int_{F c y} z^{2} d F
$$

The axes $x, y, z$ will be considered below as the principal and central ones for the cable sections. Then (2)-(5) are simplified:

$$
\begin{aligned}
& N=E F u_{0}^{\prime} \\
& M_{z}=E J_{z} \theta_{3}^{\prime}, M_{y}=E J_{y} \theta_{2}^{\prime} \\
& Q_{y}=G F_{c y}\left(-\theta_{3}+v_{0}^{\prime}\right), Q_{z}= \\
& =G F_{c z}\left(\theta_{2}+w_{0}^{\prime}\right) \\
& M_{k}=G J_{k} \theta_{1}^{\prime}
\end{aligned}
$$

Formulas (6)-(9) are accepted as basic physical relations, where the $E F$ tensile-compressive, $E J_{z}, E J_{y}$ flexural, $G F_{c y}, G F_{c z}$ shear and $G J_{k}$ torsional stiffnesses can be calculated analytically by formulae that take into account the internal structure of the cable [7-9], or by formulae obtained experimentally [10].

\section{THE PROBLEM OF THE SYSTEM NATURAL OSCILLATIONS}

According to the D'Alembert-Lagrange principle, the variation of the total energy of the system is represented as 


$$
\delta \ni=\delta U-\delta A_{p}-\delta A_{i}=0 .
$$

Here $\delta U$ is the variation of the cable deformation potential energy: $\delta A_{p}, \delta A$ - variations of the external and inertial forces work:

$$
\begin{aligned}
& \delta A_{p}=\int_{S} p \cdot \delta u d S \\
& \delta A_{i}=-\int_{V} \rho \ddot{u} \cdot \delta u d V
\end{aligned}
$$

where $u$ is the displacement vector of the body point, $p$ is the load acting on the surface $\mathrm{S}$; finally, $\rho, V$ are the density and volume of the body. In problems of natural oscillations

$$
\delta A_{p}=0
$$

The dynamic equations following from (10) have the form of Euler-Lagrange equation, and their natural boundary conditions appear.

High-frequency lateral vibrations are neglected below, since the damper is designed to suppress only low-frequency transverse vibrations. To simplify the problem, we will also neglect the shears strains using the relations

$$
\theta_{2}=-w_{0}^{\prime}, \theta_{3}=v_{0}^{\prime} \text {. }
$$

It is also considered that the bending stiffness is

$$
E J_{y}=E J_{z}=E J,
$$

the section moments of inertia are

$$
I_{y}=I_{z}=I
$$

and the polar moment of inertia is denoted by

$$
I_{x}=I_{p} .
$$

Thus, the equations of vibrations after the exclusion of transverse forces are written in the form (11)

$$
\begin{aligned}
& E J v_{0}^{I V}-I \ddot{v}_{0}^{\prime \prime}+m \ddot{v}_{0}=0, \\
& E J w_{0}^{I V}+I \ddot{w}_{0}^{\prime \prime}+m \ddot{w}_{0}=0, \\
& -G J_{k} \theta_{1}^{\prime \prime}+I_{p} \ddot{\theta}_{1}=0 .
\end{aligned}
$$

The boundary conditions at $x=l$ take the form

$$
\begin{aligned}
& Q_{y}(l)+M^{(2)}\left[\ddot{v}_{0}(l)+x_{C}^{(2)} \ddot{\theta}_{3}(l)-\right. \\
& \left.-z_{C}^{(2)} \ddot{\theta}_{1}(l)\right]=0 \\
& Q_{z}(l)+M^{(2)}\left[\ddot{w}_{0}(l)-x_{C}^{(2)} \ddot{\theta}_{2}(l)+\right. \\
& \left.+y_{C}^{(2)} \ddot{\theta}_{1}(l)\right]=0 \\
& M_{k}(l)+M^{(2)}\left[-z_{C}^{(2)} \ddot{v}_{0}(l)+y_{C}^{(2)} \ddot{w}_{0}(l)\right]+ \\
& +I_{x x}^{(2)} \ddot{\theta}_{1}-I_{x y}^{(2)} \ddot{\theta}_{2}-I_{x z}^{(2)} \ddot{\theta}_{3}=0, \\
& M_{y}(l)-M^{(2)} x_{C}^{(2)} \ddot{w}_{0}(l)-I_{x y}^{(2)} \ddot{\theta}_{1}+I_{y y}^{(2)} \ddot{\theta}_{2}- \\
& -I_{y z}^{(2)} \ddot{\theta}_{3}=0 \\
& M_{z}(l)+M^{(2)} x_{C}^{(2)} \ddot{v}_{0}(l)-I_{x z}^{(2)} \ddot{\theta}_{1}-I_{y z}^{(2)} \ddot{\theta}_{2}+ \\
& +I_{z z}^{(2)} \ddot{\theta}_{3}=0 .
\end{aligned}
$$

where $M^{(\mathrm{r})}$ is the mass of the load; $x_{C}^{(\Gamma)}, y_{C}^{(\Gamma)}, z_{C}^{(\Gamma)}$ and $I_{i j}^{(\Gamma)}(i, j=x, y)$ are the coordinates of the mass gravity center and its moments of inertia relative to the trihedron of the moving axes $O^{\prime} x^{\prime} y^{\prime} z$.

The solution of (11) are:

$$
\begin{aligned}
& v_{0}=\sin \omega t\left(A_{1} \sin a x+\right. \\
& \left.+A_{2} \cos a x+A_{3} \operatorname{sh} b x+A_{4} \operatorname{ch} b x\right), \\
& w_{0}=\sin \omega t\left(B_{1} \sin a x+\right. \\
& \left.+B_{2} \cos a x+B_{3} \operatorname{sh} b x+B_{4} \operatorname{ch} b x\right), \\
& \theta_{1}=\sin \omega t\left(D_{1} \sin k x+D_{2} \cos k x\right),
\end{aligned}
$$

where $A_{1,2,3,4}, B_{1,2,3,4}, D_{1,2}$ are the constants of integration, $\omega=\omega_{i}(i=1,2, \ldots)$ are the natural frequencies;

$$
\begin{aligned}
& a^{2}=\frac{1}{2 E J}\left(\omega^{2} I+\omega \sqrt{\omega^{2} I^{2}+4 E J m}\right), \\
& b^{2}=\frac{1}{2 E J}\left(-\omega^{2} I+\omega \sqrt{\omega^{2} I^{2}+4 E J m}\right) ; \\
& k^{2}=\omega^{2} \frac{I_{p}}{G J_{k}} .
\end{aligned}
$$

Taking into account the console pinning at $x=0$, the solution takes the form

$$
\begin{aligned}
& v_{0}=\sin \omega t\left(A_{1} \varphi_{1}+A_{2} \varphi_{2}\right), w_{0}= \\
& \sin \omega t\left(B_{1} \varphi_{1}+B_{2} \varphi_{2}\right), \\
& \theta_{1}=D \sin \omega t \sin k x,
\end{aligned}
$$

where we have the eigenforms:

$$
\begin{aligned}
& \varphi_{1}(x)=\operatorname{sh} b x-\frac{b}{a} \cdot \sin a x, \varphi_{2}(x)=\operatorname{ch} b x- \\
& -\cos a x
\end{aligned}
$$


The constants $A_{1,2}, B_{1,2}$ and $D$ are found from the boundary conditions (23) at $x=1$. Substituting (13), (14) into (12) leads to a homogeneous system of five equations with respect to the required five constants. The equality of determinant to zero is the nontriviality condition of the system solution

$$
\Delta(\omega)=0,
$$

the roots of which are the frequencies of the system natural oscillations:

$$
\omega_{i}, i=1,2, \ldots .
$$

The search for the transcendental equation roots (15) of a very complex structure can be carried out by a step-by-step method, changing the frequency $\omega$ with some small step $\Delta \omega$ from zero to some selected value. When changing the sign of the determinant, some numerical method is used, for example, the method of dividing in half.

\section{DESCRIPTION OF THE NON- STATIONARY PROCESS HYSTERESIS}

To describe the hysteresis under the conditions of nonstationary oscillations, we propose an ordinary differential equation of the first order [4-6] with the right-hand side of the form

$$
\frac{d M}{d \kappa}=\sum_{i=1}^{k} \sum_{j=1}^{m} C_{i j} \kappa^{i-1} M^{j-1}
$$

where $\kappa$ is the bending curvature of the cable, $M$ is the bending moment; $C_{i j}$ are the coefficients determined by approximation methods, minimizing the discrepancy of the analytical representation $\frac{d M}{d \kappa}$ (16) to the experimental data describing the limit cycle.

It is assumed that all possible hysteresis trajectories - dependences $M(\kappa)$ lie within the limit cycle, i.e., the region bounded by curves $M(\kappa)$ corresponding to the maximum ranges of curvature and moment changes. The numbers $\mathrm{k}$ and $\mathrm{m}$ are selected as a result of simple numerical tests. The values of these parameters determine the character (speed) of the asymptotic approximation of the solution with the initial point $\left(\kappa_{0}, M_{0}\right)$ inside the domain to the limit cycle curves.

The values $C_{i j}$ can be calculated using the least squares method, for instance.

An example of the dependencies $M(\kappa)$ obtained experimentally in [11] is given in Figure 3. The bold lines correspond to the limit cycle. The thin lines correspond to possible loop-like trajectories within the limit cycle region. Trajectories for which the curvature increases with increasing moment correspond to the process of "loading". Conversely, trajectories for which the curvature decreases as the moment decreases correspond to the "unloading" process. The beginning of the process is determined by some point inside the limit cycle area.

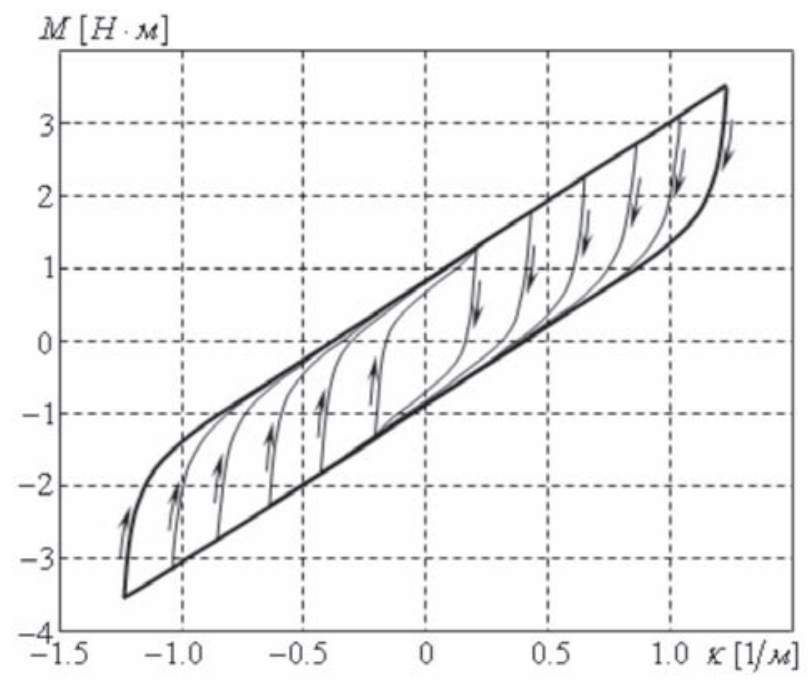

Figure 3. Hysteresis trajectories.

"Loading" processes are marked with up arrows, "unloading" - with down arrows. Bold curves limit the area of the limit cycle. Thindefine possible trajectories of intermediate States

Next, the following notation is introduced:

$$
\kappa_{y}=-w_{0}^{\prime \prime}, \kappa_{y}=-w_{0}^{\prime \prime}, \kappa_{k}=\theta_{1}^{\prime} .
$$

Based on (16) and the introduced curvature notation 


$$
\frac{d M_{y}}{d \kappa_{y}}=\Phi_{y}, \frac{d M_{z}}{d \kappa_{z}}=\Phi_{z}, \frac{d M_{k}}{d \kappa_{k}}=\Psi,
$$

Where

$$
\begin{aligned}
& \Phi_{y}=\sum_{i=1}^{k} \sum_{j=1}^{m}(-1)^{i-1} C_{i j}\left(w_{0}^{\prime \prime}\right) M_{y}^{j-1}, \\
& \Phi_{z}=\sum_{i=1}^{k} \sum_{j=1}^{m} C_{i j}\left(v_{0}^{\prime \prime}\right) M_{z}^{j-1}, \\
& \Psi=\sum_{i=1}^{k} \sum_{j=1}^{m} D_{i j}\left(\theta_{1}^{\prime}\right)^{i-1} M_{k}^{j-1} .
\end{aligned}
$$

The equations follow from (17)

$$
\begin{gathered}
\dot{M}_{y}=-\dot{w}_{0}^{\prime \prime} \Phi_{y}, \\
\dot{M}_{z}=\dot{v}_{0}^{\prime \prime} \Phi_{z}, \\
\dot{M}_{z}=\dot{\theta}_{1}^{\prime} \Psi,
\end{gathered}
$$

that must be integrated together with the equations of forced oscillations in the form:

$$
\begin{aligned}
& M_{z}^{\prime \prime}-I \ddot{v}_{0}^{\prime \prime}+m \ddot{v}_{0}=f_{y} ; \\
& -M_{y}^{\prime \prime}+I \ddot{w}_{0}^{\prime \prime}+m \ddot{w}_{0}=f_{z} ; \\
& -M_{1}^{\prime}+I_{p} \ddot{\theta}_{1}=f_{k} .
\end{aligned}
$$

Here, $f_{y}(t, x), f_{z}(t, x)$ and $f_{k}(t, x)$ is the specified external distributed load.

The unknowns of the system (19), (20) are $v_{0}, w_{0}$, $\theta_{1}, M_{y}, M_{z}, M_{k}$.

The solution is constructed using the expansion with respect to the eigenforms of vibrations of the undamped system:

$$
\begin{aligned}
& v_{0}(t, x)=\sum_{i=0}^{r} \alpha_{i}(t) V_{i}(x), w_{0}(t, x)= \\
& \sum_{i=0}^{r} \beta_{i}(t) W_{i}(x), \\
& \theta_{1}(t, x)=\sum_{i=0}^{r} \gamma_{i}(t) \Theta_{i}(x), \\
& M_{y}(t, x)=\sum_{i=0}^{r} \mu_{i}(t) W_{i}^{\prime \prime}(x), M_{z}(t, x)= \\
& \sum_{i=0}^{r} v_{i}(t) V_{i}^{\prime \prime}(x), \\
& M_{k}(t, x)=\sum_{i=0}^{r} \eta_{i}(t) \Theta_{i}^{\prime}(x),
\end{aligned}
$$

where the waveforms (22)

$$
\begin{aligned}
& V_{i}(x)=A_{1 i} \varphi_{1 i}(x)+A_{2 i} \varphi_{2 i}(x), W_{i}(x)= \\
& B_{1 i} \varphi_{1 i}(x)+B_{2 i} \varphi_{2 i}(x), \\
& \Theta_{i}(x)=D_{i} \sin k_{i} x
\end{aligned}
$$

are determined from the solution of the spectral problem; index $i$ is the number of natural frequency of vibrations; $r$ is the number of considered natural forms of vibrations; the value $i=0$ corresponds to the unit forms that determine the motion of the system as a solid. The functions $\alpha_{i}(t), \beta_{i}(t), \gamma_{i}(t)$, $\mu_{i}(t), v_{i}(t), \eta_{i}(t)$ are to be defined. Substituting (21) with (22) in (19), (20) leads to a system of equations

$\sum_{i=0}^{r}\left(\dot{\mu}_{i} W_{i}^{\prime \prime}+\dot{\beta}_{i} \Phi_{y} W_{i}^{\prime \prime}\right)=0$,

$\sum_{i=0}^{r}\left(\dot{v}_{i} V_{i}^{\prime \prime}-\dot{\alpha}_{i} \Phi_{z} V_{i}^{\prime \prime}\right)=0, \quad \sum_{i=0}^{r}\left(\dot{\eta}_{i} \Theta_{i}^{\prime}-\right.$

$\left.\dot{\gamma}_{i} \Psi \Theta_{i}^{\prime}\right)=0$,

$\sum_{i=0}^{r}\left[\ddot{\alpha}_{i}\left(m V_{i}-I V_{i}^{\prime \prime}\right)+v_{i} V_{i}^{I V}\right]=f_{y}$,

$\sum_{i=0}^{r}\left[\ddot{\beta}_{i}\left(m W_{i}-I W_{i}^{\prime \prime}\right)-\mu_{i} W_{i}^{I V}\right]=f_{z}$,

$\sum_{i=0}^{r}\left(\ddot{\gamma}_{i} I_{p} \Theta_{i}-\eta_{i} \Theta_{i}^{\prime \prime}\right)=f_{k}$.
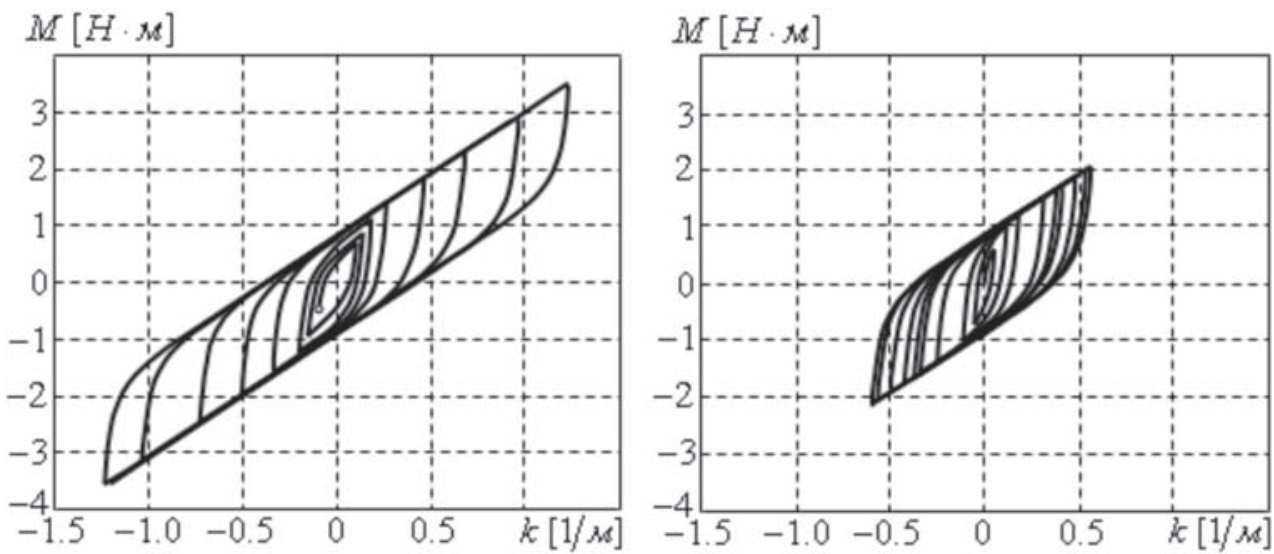

Figure 4. Characteristic hysteresis loops under different initial conditions and external excitation 
Sequential multiplication of the (23) by the corresponding oscillation forms $V_{m}, W_{m}, \Theta_{m}(m=$ $1, \ldots, r)$ and integration along the length of the cable leads to the initial problem for the system of ordinary differential equations with respect to относительно $\alpha_{i}(t), \beta_{i}(t), \gamma_{i}(t), \mu_{i}(t), v_{i}(t), \eta_{i}(t)$. This system is integrated by numerical methods. Some characteristic hysteresis trajectories obtained as a result of solving the nonstationary equations (23) are shown in Figure 4.

\section{CONCLUSIONS}

In this paper, we propose an approach to solving problems of multi-frequency vibration dampers of OL wires non-stationary oscilations, taking into account the energy dissipation of the hysteresis type. To account for energy scattering, a phenomenological method based on the use of kinematic equations, the coefficients of which are determined from the analysis of experimental data for limit cycles, is proposed. This approach can be extended to the problems of non-stationary vibrations of other mechanical objects with a hysteresis character of energy scattering.

\section{ACKNOWLEDGEMENTS}

The research was funded by the RFBR, project numbers 20-08-00891 and 19-08-00938.

\section{REFERENCES}

1. Stockbridge G.H. Vibration damper. U.S. Patent 1675391. Filling date: Nov 12, 1925. Issue date: Jul 3, 1928.

2. McCombe J., Haigh F.R. Overhead Line Practice (3rd ed.). Macdonald, 1966, pp. 216-219.

3. Shkaptsov V.A. Metodicheskie ukazanija po tipovoj zashhite ot vibracii i subkolebanij provodov i grozozashhitnyh trosov vozdushnyh linij jelektroperedachi naprjazheniem 35$750 \mathrm{kV}$ [Methodical instructions on typical protection against vibration and sub-vibrations of wires and lightning protection cables of overhead power lines with voltage of 35-750 kV]. Moscow, SPO “ORGRES”, 1991, 68 pages (in Russian).

4. Danilin A.N., Vinogradov A.A., Lilien J.-L. A Kinematic Model for Hysteretic Dissipation of Vibration Energy for Torsional Damper and Detuner (TDD). Proc. of Seventh International Symposium on Cable Dynamics, Vienna (Austria), December 10-13, 2007, pp. 247-253.

5. Danilin A.N., Shalashilin V.I. Sposob identifikacii gisterezisa na primere gasitelja "pljaski provodov" [A method for identifying hysteresis on the example of a dampener "dances of wires"]. // Applied Mechanics, 2010, Vol. 46, No. 5, pp. 115-124 (in Russian).

6. Danilin A.N., Kozlov K.S. Modelirovanie kolebanij mnogochastotnogo gasitelja vibracii s uchetom gisterezisa dissipacii jenergii [Modeling of vibrations of a multi-frequency vibration damper taking into account the hysteresis of energy dissipation]. // Proceedings of the IX all-Russian scientific conference named after Yu.I. Neymark "Nonlinear oscillations of mechanical systems”. Nizhny Novgorod, September 24-29, 2012, pp. 320329 (in Russian).

7. Shalashilin V.I., Danilin A.N., Tsvetkov Yu.L., Ryzhov S.V. Model' provoda vozdushnoj linii jelektroperedachi [Model of an overhead power line wire]. // Mechanics of composite materials and structures, 2005, Vol. 11, No. 4, pp. 564-572 (in Russian).

8. Shalashilin V.I., Danilin A.N., VolkovBogorodskiy D.B. Model of overhead line conductor with interaction of layers. // Proceedings of Sixth International Symposium on Cable Dynamics. Charleston, South Carolina (U.S.A.), Sept 19-22, 2005, pp. 371-377.

9. Danilin A.N., Kuznetsova E.L., Rabinsky L.N., Tarasov S.S. New model of deformation of wire systems of spiral structure. // Nonlinear world, 2011, Vol. 9, No. 10, pp. 635-645.

10. Dubois H., Lilien J.L., Dal Maso F. A new theory for frequencies computation of 
overhead lines with bundle conductors. // Revue AIM (Belgium), 1991, No 1, pp. 45-62.

11. Sauter D., Hagedorn P. On the hysteresis of wire cables in stockbridge dampers. // Int. J. of Non-linear Mechanics, 2002, Vol. 37, No. 8, pp. 1453-1459.

\section{СПИСОК ЛИТЕРАТУРЫ}

1. Stockbridge G.H. Vibration damper. U.S. Patent 1675391. Filling date: Nov 12, 1925. Issue date: Jul 3, 1928.

2. McCombe J., Haigh F.R. Overhead Line Practice (3rd ed.). Macdonald, 1966, pp. 216-219.

3. Шкапцов В.А. Методические указания по типовой защите от вибрации и субколебаний проводов и грозозащитных тросов воздушных линий электропередачи напряжением 35-750 кВ. - М.: СПО ОРГРЭС, 1991. $-68 \mathrm{c}$.

4. Danilin A.N., Vinogradov A.A., Lilien J.-L. A Kinematic Model for Hysteretic Dissipation of Vibration Energy for Torsional Damper and Detuner (TDD). Proc. of Seventh International Symposium on Cable Dynamics, Vienna (Austria), December 10-13, 2007, pp. 247-253.

5. Данилин А.Н., Шалашилин В.И. Способ идентификации гистерезиса на примере гасителя «пляски проводов». // Прикладная механика, 2010, том 46, №5, с. 115-124.

6. Данилин А.Н., Козлов К.С. Моделирование колебаний многочастотного гасителя вибрации с учетом гистерезиса диссипа- ции энергии. // Труды IX всероссийской научной конференции им. Ю.И. Неймарка «Нелинейные колебания механических систем». - Нижний Новгород, 24-29 сентября 2012 г. Нижний Новгород: Издательский дом «Наш дом», с. 320-329.

7. Шалашилин В.И., Данилин А.Н., Цветков Ю.Л., Рыжов СВ. Модель провода воздушной линии электропередачи. // Механика композиционных материалов и конструкций, 2005, том 11, №4, с. 564-572.

8. Shalashilin V.I., Danilin A.N., Tsvetkov Yu.L., Ryzhov S.V. Model of an overhead power line wire. // Mechanics of composite materials and structures, 2005, Vol. 11, No. 4, pp. 564-572.

9. Shalashilin V.I., Danilin A.N., VolkovBogorodskiy D.B. Model of overhead line conductor with interaction of layers. // Proceedings of Sixth International Symposium on Cable Dynamics. Charleston, South Carolina (U.S.A.), Sept 19-22, 2005, pp. 371-377.

10. Danilin A.N., Kuznetsova E.L., Rabinsky L.N., Tarasov S.S. New model of deformation of wire systems of spiral structure. // Nonlinear world, 2011, Vol. 9, No. 10, pp. 635-645.

11. Dubois H., Lilien J.L., Dal Maso F. A new theory for frequencies computation of overhead lines with bundle conductors. // Revue AIM (Belgium), 1991, No 1, pp. 45-62.

12. Sauter D., Hagedorn P. On the hysteresis of wire cables in stockbridge dampers. // Int. J. of Non-linear Mechanics, 2002, Vol. 37, No. 8, pp. 1453-1459.
Danilin Alexander Nikolaevich, Ph.D., Leading researcher of the Department of Mechanics of Smart and Composite Materials and Systems, Institute of Applied Mechanics of Russian Academy of Sciences (IAM RAS); Associate Professor of the Department of Mechanics of nanostructured materials and systems, Moscow Aviation Institute (National Research University) - MAI; 7, Leningradskiy Prospekt, Moscow, 125040, Russia, IAM RAS; phone: +7(916)5336982; e-mail: andanilin@yandex.ru.
Kurbatov Alexey Sergeevich, Ph.D., Researcher of the Department of Mechanics of Smart and Composite Materials and Systems, Institute of Applied Mechanics of Russian Academy of Sciences (IAM RAS); Associate Professor of the Department of Mechanics of nanostructured materials and systems, Moscow Aviation Institute (National Research University) - MAI; 7, Leningradskiy Prospekt, Moscow, 125040, Russia, IAM RAS; phone: +7(963)648-7362; E-mail: defunt@inbox.ru. 
Zhavoronok Sergey Igorevich, Ph.D., Senior researcher of the Department of Mechanics of Smart and Composite Materials and Systems, Institute of Applied Mechanics of Russian Academy of Sciences (IAM RAS); Associate Professor of the Department of Strength of Materials, Machine Dynamics and Strength, Moscow Aviation Institute (National Research University) MAI; 7, Leningradskiy Prospekt, Moscow, 125040, Russia, IAM RAS; phones: +7(495)941-1777; +7(916)134-2843; E-mail: Zhavoronok@iam.ras.ru, zhavor71@mail.ru.

Данилин Александр Николаевич, доктор физико-математических наук, главный научный сотрудник ФГБУН Института прикладной механики РАН; федеральное государственное бюджетное образовательное учреждение высшего профессионального образования «Московский авиационный институт (национальный исследовательский университет)» (МАИ); 125040, Россия, г. Москва, Ленинградский проспект, дом 7; тел. +7(916)533-6982; e-mail: andanilin@yandex.ru.

Курбатов Алексей Сергеевич, кандидат физико-математических наук; научный сотрудник отдела меха- ники интеллектуальных и композитных материалов и систем, ФГБУН Института прикладной механики РАН; федеральное государственное бюджетное образовательное учреждение высшего профессионального образования «Московский авиационный институт (национальный исследовательский университет)» (МАИ); 125040, Россия, г. Москва, Ленинградский проспект, дом 7; тел.: +7(963)648-7362; E-mail: defunt@inbox.ru.

Жаворонок Сергей Игоревич, доцент, кандидат физико-математических наук, старший научный сотрудник отдела механики интеллектуальных и композитных материалов и систем, ФГБУН Института прикладной механики РАН; федеральное государственное бюджетное образовательное учреждение высшего профессионального образования «Московский авиационный институт (национальный исследовательский университет)» (МАИ) 125040, Россия, г. Москва, Ленинградский проспект, дом 7; Тел.: +7(495)9411777; +7(916)134-2843. E-mail: Zhavoronok@iam.ras. ru, zhavor71@mail.ru 